\title{
PERBANDINGAN UJI KEMAMPUAN BAWANG PUTIH (Allium sativum) DENGAN JAHE (Zingiber officinale) SEBAGAI ANTIMIKROBA PADA IKAN SEGAR Hj. Inayah ${ }^{1}$ dan Andi Marlinda Gereng ${ }^{2}$ \\ 1,2Jurusan Kesehatan Lingkungan Poltekkes Kemenkes Makassar andimarlinda22@gmail.com
}

\begin{abstract}
Fish is a variety of meat that spoils particularly quickly, especially fresh fish. This spoiling takes places because of an increase in microbial growth. One strategy to lessen, inhibit or prevent the progress of microbial growth in fish is by the use of antimicrobials. Among the general public, two of the most commonly used natural antimicrobials are garlic and ginger. The goal of this research is to better understand the differences in effectiveness between garlic (Allium sativum) and ginger (Zingeber officinale) as an antimicrobial for fresh fish. This research was conducted by experimentation. Mackerel fish purchased at the Patompo Market on Nuri Baru Street in Makassar. The sample in this study is 10 mong bloated fish with replication 2 times. The results of this research shows that the fish preserved with garlic (Allium sativum) saw a drop in bacteria equivalent to 113.750 colony/gram after 8 hours. After 10 hours, this number rose to 240.800 colony/gram and rose further to 576.000 colony/gram after a 12 hour period of time. The fish that was preserved with ginger (Zingeber officinale), on the other hand, had a drop in bacteria equivalent to 106.475 colony/gram after 8 hours, 229.500 colony/gram after 10 hours, and 229.500 colony/gram after 12 hours. In summary, this research has shown that garlic (Allium sativum) has a stronger ability as a antimicrobial than ginger (Zingeber officinale). Is expected to the public to utilize garlic and ginger as a natural preservative $i$ fresh fish.
\end{abstract}

Key Words: Garlic, Ginger, Natural Antimicrobials

\section{ABSTRAK}

Ikan merupakan salah satu bahan pangan yang mudah rusak, terutama ikan segar. Kerusakan ikan terjadi karena adanya pertumbuhan mikroba yang meningkat. Salah satu strategi untuk mengurangi atau menghambat pertumbuhan mikroba dapat dilakukan dengan mengaplikasikan antimikroba pada saat proses pengolahan pangan untuk mencegah pertumbuhan mikroba. Antimikroba alami yang populer dikalangan masyarakat yaitu bawang putih dan jahe. Penelitian ini bertujuan untuk mengetahui apakah terdapat perbedaan kemampuan bawang putih (Allium sativum) dengan jahe (Zingiber officinale) sebagai antimikroba pada ikan segar. Jenis penelitian yang digunakan adalah eksperimen. Sampel dalam penelitian ini adalah ikan kembung sebanyak 20 ekor dengan berat 100 gram - $105 \mathrm{gram}$. Analisa dengan tabel terhadap rata-rata penurunan angka lempeng total dengan replikasi 2 kali.Hasil penelitian ini adalah pemberian pelumuran dengan bawang putih selama 8 jam mengalami penurunan bakteri sebanyak 113.750 koloni/gram, selama 10 jam penurunan bakteri sebanyak 240.800 koloni/gram, dan untuk selama 12 jam penurunan bakteri sebanyak 576.000 koloni/gram. Untuk pelumuran dengan jahe diperoleh hasil saat 8 jam penurunan bakteri sebanyak 106.475 koloni/gram, saat 10 jam penurunan bakteri sebanyak 229.500 koloni/gram, dan saat 12 jam penurunan bakteri sebanyak 558.000 koloni/gram. Kesimpulan pada penelitian ini adalah bawang putih (Allium sativum) memiliki kemampuan sebagai antimikroba lebih besar dibanding dengan kemampuan jahe (Zingeber officinale) sebagai antimikroba. Diharapkan kepada masyarakat untuk memanfaatkan bawang putih dan jahe sebagai pengawet alami pada ikan segar.

Kata Kunci: Bawang putih, Jahe, Antimikroba alami

\section{PENDAHULUAN}

Bahan makanan terdiri dari protein, karbohidrat, lemak, vitamin, dan mineral. Bahan makanan merupakan medium pertumbuhan yang baik bagi berbagai macam mikroorganisme. Mikroorganisme dapat membusukkan protein, memfermentasikan karbohidrat dan menjadikan lemak serta minyak berbau tengik. Beberapa mikroorganisme pencemaran dapat mengakibatkan kerusakan, menimbulkan penyakit atau mengahasilkan racun yang menyebabkan keracunan makanan. Kasus penyakit infeksi oleh bakteri patogen dan kasus kerusakan pangan, keduanya diakibatkan oleh pertumbuhan mikroba yang tidak diinginkan dalam bahan pangan (Afrianti, 2013).
Ikan merupakan salah satu bahan pangan yang mudah rusak, terutama ikan segar. Ikan cepat mengalami proses pembusukan dibandingkan dengan bahan makanan lain yang disebabkan oleh bakteri dan perubahan kimiawi pada ikan mati. Ikan segar atau ikan basah adalah ikan yang belum atau tidak diawetkan dengan bahan apapun kecuali didinginkan dengan es Ikan merupakan sumber pangan yang mudah rusak karena sangat cocok untuk pertumbuhan mikroba baik patogen maupun non-patogen. Kerusakan ikan terjadi segera setelah ikan keluar dari air. Kerusakan dapat disebabkan oleh faktor internal (isi perut) dan eksternal (lingkungan) maupun cara penanganan di atas kapal, di tempat pendaratan atau di tempat pengolahan (Susanti, 2013). 
Jurnal Sulolipu : Media Komunikasi Sivitas Akademika dan Masyarakat

Vol. 17 No.II 2017

e-issn : 2622-6960, p-issn : 0854-624X

Dasar pengawetan ikan adalah mempertahankan ikan selama mungkin dengan cara menghambat atau menghentikan beberapa aktivitas bakteri pembusuk yang ada pada tubuh ikan. Pengawetan merupakan upaya yang dilakukan untuk memperpanjang waktu penyimpanan bahan pangan.

Pada perkembangannya mikroba dapat dihambat dengan adanya zat antimikroba yang dapat menekan laju pertumbuhan mikroba. Zat antimikroba mempunyai peranan penting selain menekan laju pertumbuhan bakteri patogen tetapi juga bakteri perusak yang sama-sama tidak diinginkan (Siburian dkk., 2012).

Salah satu strategi untuk mengurangi jumlah bakteri dapat dilakukan dengan mengaplikasikan antimikroba pada saat proses pengolahan pangan untuk mencegah pertumbuhan mikroba. Penggunaan rempah rempah dalam makanan, tidak hanya memberi karakteristik rasa, kepedasan, dan warna, melainkan juga memberikan aktivitas antioksidan dan antimikroba, farmaseutikal, dan nilai gizi. Antibakteri pada bahan alami digunakan untuk mengontrol pembusukan dan mencegah tumbuhya mikroorganisme seperti mikroorganisme pathogen (Susanto, 2011). Antibakteri alami yang populer dikalangan masyarakat yaitu bawang putih, jahe dan bahan lainnya.

Bawang putih sangat mudah diperoleh di seluruh Indonesia, selain itu bawang putih merupakan salah satu bumbu dapur yang sangat lazim digunakan di dalam masakan dan tidak menimbulkan perubahan cita rasa. Penggunaan bawang putih tidak hanya sebagai bahan penyedap rasa, tetapi digunakan juga sebagai salah satu bahan yang dapat memberikan efek kesehatan seperti menghambat pertumbuhan bakteri patogen (Lestari, 2016).

Louis Pasteur menyatakan bahwa terdapat daya antimikroba pada bawang putih mentah atau pada jus bawang putih. Sudah sejak zaman dahulu, bawang putih telah digunakan masyarakat secara luas untuk mengobati infeksi. Bawang putih mempunyai spektrum antimikroba yang lebar sehingga dapat membunuh bakteri gram negatif dan bakteri gram posit (Ramadanti, 2008).

Sebagai bumbu dapur, bawang putih mempunyai peranan penting dalam melezatkan dan menimbulkan aroma yang sedap pada masakan. Akan tetapi selain sebagai bumbu, bawang putih memiliki khasiat yang luar biasa bagi kesehatan.
Jahe dikenal sebagai rempah-rempah, beberapa abad yang lalu jahe merupakan salah satu bahan yang penting di China. Antibakteri pada bahan alami digunakan untuk mengontrol pembusukan dan mencegah tumbuhya mikroorganisme seperti mikroorganisme pathogen.

Kemampuan bawang putih sebagai antibakteri dalam menghambat pertumbuhan jumlah bakteri didukung oleh penelitian Nilam Syifa dkk., (2013) yang menyatakan bahwa ekstrak bawang putih yang dilarutkan dalam air bersifat antibakteri terhadap bakteri gram positif dan gram negatif, pemberian ekstrak bawang putih efektif menghambat pertumbuhan bakteri dengan konsentrasi paling efektif $10 \%$ serta waktu penyimpanan maksimal adalah 24 jam. Ekstrak bawang putih menggunakan pelarut aquades steril pada suhu ruang (antara $25-27^{\circ} \mathrm{C}$ ) dapat menghasilkan allicin sebagai zat antibakteri yang menghambat pertumbuhan koloni bakteri. Pernyataan yang sama oleh Hernawan dkk., (2003) bahwa ekstraksi menggunakan air akan menghasilkan allicin pada suhu sekitar $25^{\circ} \mathrm{C}$.

Kemampuan jahe sebagai antibakteri dalam menghambat pertumbuhan jumlah bakteri didukung oleh penelitian Handrianto, (2016) bahwa ekstrak segar jahe merah (Zingiber officinale var. rubrum) pada konsentrasi $100 \%$ mempunyai tingkat daya hambat sedang terhadap $S$. aureus dan lemah terhadap E. coli. Selain itu penelitian yang dilakukan Eko Susanto dkk., yakni memanfaatkan daun sosor bebek (Kalanchoe pinnata Lamk.Pers) dan jahe merah (Zingiberofficinalle var. amarum) sebagai pengawet alami pada ikan kembung (Rastrelliger neglectus) yang didinginkan dengan perbandingan ikan dan es yang berbeda memperoleh hasil perlakuan terbaik dihasilkan dari perlakuan rasio ikan dan es 1:1. Kedua bahan alami dapat digunakan sebagai alternatif untuk memperpanjang daya tahan ikan kembung. Hasil penelitian Hijriy dkk., (2015) menunjukkan bahwa konsentrasi yang paling baik menghambat jumlah koloni bakteri adalah konsentrasi $70 \%$ dengan lama perendaman ikan tongkol pada sari jahe selama 105 menit yang masih berada dibawah SNI 2009 tentang cemaran mikroba pada pangan $\left(5 \times 10^{5}\right)$ yaitu $1,8 \times 10^{5}$.

Senyawa metabolit sekunder yang dihasilkan tumbuhan Zingiberaceae ini umumnya dapat menghambat pertumbuhan patogen yang merugikan kehidupan manusia, diantaranya bakteri Escherichia coli dan Bacillus subtilis, serta beberapa mikroba lainya (Hadrianto, 2006.) 
Pengujian mutu kesegaran ikan penting untuk meningkatkan tingkat konsumsi ikan (konsumsi protein). Jika penanganan pada ikan kurang tepat, protein yang terkandung dalam ikan akan dimanfaatkan oleh mikroorganisme untuk berkembang biak dan menjadikan kualitas ikan menurun. Kualitas ikan yang menurun dapat menyebabkan sakit pada orang yang mengkonsumsinya.

Berbagai penelitian telah dilakukan untuk mengetahui khasiat bawang utih dan jahe, namun keterbatasan informasi yang diterima masyarakat dan adanya pergeseran pola hidup masyarakat ke arah modern mengakibatkan khasiat bawang putih dan jahe mulai dilupakan masyarakat

Adapun tujuan dalam penelitian ini adalah:

1. Tujuan Umum

Untuk membandingkan kemampuan bawang putih (Allium sativum) dengan jahe (Zingiber officinale) sebagai antimikroba pada ikan segar.

2. Tujuan Khusus

a. Untuk mengetahui kemampuan bawang putih (Allium sativum) dalam menghambat pertumbuhan mikroba pada ikan segar.

b. Untuk mengetahui kemampuan jahe (Zingiber officinale) dalam menghambat pertumbuhan mikroba pada ikan segar.

\section{BAHAN DAN METODE}

\section{Jenis Penelitian}

Jenis penelitian yang digunakan adalah eksperimen yaitu untuk melihat kemampuan bawang putih dan jahe sebagai antimikroba pada ikan segar.

2. Lokasi dan Waktu Penelitian

\section{a. Lokasi Pengambilan Sampel}

Lokasi pengambilan sampel ikan segar yaitu di Pasar Patompo, Jalan Nuri Baru, Makassar.

\section{b. Lokasi Pemeriksaan}

Lokasi untuk melakukan pemeriksaan angka lempeng total (ALT) dan organoleptik adalah di Laboratorium Politeknik Kesehatan Makassar, Jurusan Kesehatan Lingkungan.

\section{c. Waktu penelitian}

i. Tahap persiapan yang meliputi pengumpulan data sekunder dan penyusunan proposal yang berlangsung pada bulan Desember 2016 - Januari 2017.

ii. Tahap pelaksanaan meliputi kegiatan penelitian yaitu pengamatan organoleptik dan pemeriksaan ALT pada ikan segar yang berlangsung pada bulan April - Mei 2017.

\section{d. Variabel Penelitian}

i. Variabel bebas yaitu proses pelumuran dengan menggunakan bawang putih (Allium sativum) dan jahe (Zingiber officinale).

ii. Variabel terikat adalah organoleptik dan penurunan angka lempeng total pada ikan segar .

iii. Variabel pengganggu mencakup jenis ikan, berat bawang putih, berat jahe, dan suhu.

\section{e. Definisi Operasional dan Kriteria Objektif}

i. Ikan segar dalam penelitian ini adalah ikan yang hidup di laut, dengan ukuran rata-rata berat 100 - 105 gram, di dekat ekor ada bagian sisik yag mengeras, mempunyai garis kuning panjang pada tubuh, lingkaran mata besar. Dikenal dengan nama ikan kembung.

ii. Bawang putih (Allium sativum) dalam penelitian ini adalah tanaman yang memiliki umbi atau siung berwarna putih yang dilapisi kulit pada bagian luarnya, yang kemudian dihaluskan.

iii. Jahe (Zingiber officinale) adalah tanaman rimpang yang berbentuk jemari yang menggembung dengan ruas-ruas tengah, dan dagingnya berwarna putih, yang kemudian dihaluskan.

iv. Organoleptik pada penelitian ini merupakan ciri-ciri fisik yang ada pada bagian ikan mulai dari mata, lendir permukaan badan, daging, bau, dan tekstur, kecuali insang.

Kriteria objektif :

a) Bawang putih dan jahe dikatakan mampu sebagai antimikroba setelah proses penyimpanan selama 8 jam, 10 jam, dan 12 jam, organoleptik pada ikan tidak melebihi SNI Minimal 7 (skor 1 - 9).

b) Bawang putih dan jahe dikatakan tidak mampu sebagai antimikroba apabila setelah proses penyimpanan 8 jam, 10 jam, dan 12 jam organoleptik pada ikan melebihi SNI Minimal 7 (skor 1 9). 
v. Angka Lempeng Total (ALT) adalah jumlah koloni yang tumbuh pada media dengan menggunakan metode plate count dinyatakan dalam koloni/gram.

Kriteria Objektif :

a) Bawang putih dan jahe dikatakan mampu sebagai antimikroba apabila setelah proses penyimpanan selama 8 jam, 10 jam, dan 12 jam jumlah kuman pada ikan mengalami penurunan dan memenuhi syarat SNI 2729 : 2013 yaitu 5 x 105 koloni/gram.

b) Bawang putih dan jahe dikatakan tidak mampu sebagai antimikroba apabila setelah proses penyimpanan selama 8 jam 10 jam, dan 12 jam jumlah kuman pada ikan mengalami peningkatan dan tidak memenuhi syarat SNI 2729 : 2013 yaitu $5 \times 105$ koloni/gram.

\section{f. Sampel}

Sampel dalam penelitian ini adalah ikan kembung yang diambil di Pasar Patompo Jalan Nuri Baru. Jumlah sampel yang digunakan yaitu sebanyak 10 ekor ikan kembung dengan replikasi 2 kali.

\section{g. Analisa Data}

Data yang diperoleh dianalisa secara deskriptif, yaitu dengan mengetahui perbedaan kemampuan bawang putih (Allium sativum) dengan jahe (Zingiber officinale) dalam menghambat pertumbuhan mikroba pada ikan segar dan

\section{HASIL PENELITIAN} membandingkan dengan $\mathrm{SNI}\left(5 \times 10^{5}\right)$.

Dari hasil pemeriksaan jumlah kuman yang telah dilakukan pada ikan kembung dengan pelumuran dan tanpa pelumuran bawang putih dan pelumuran jahe masing-masing 20 gram pada 100 - 105 gram pada ikan kembung dengan waktu pelumuran berbeda yakni 8 jam, 10 jam dan 12 jam. Hasil dari penelitian tersebut dapat dilihat pada uraian dibawah ini:

\section{Pelumuran dengan Bawang Putih}

Hasil pemeriksaan jumlah kuman dengan pelumuran dan tanpa pelumuran bawang putih masing-masing 20 gram pada 100 - 105 gram pada ikan kembung dengan waktu pelumuran berbeda yakni 8 jam, 10 jam dan 12 jam yang dilaksanakan pada tanggal 9 - 10 Mei 2017, dapat dilihat pada tabel 1 berikut ini :

Tabel 1

Hasil Pemeriksaan ALT Pada Ikan Segar Dengan Pelumuran Bawang Putih

\begin{tabular}{|c|c|c|c|}
\hline \multirow[t]{2}{*}{ Perlakuan } & \multicolumn{3}{|c|}{$\begin{array}{c}\text { Angka Lempeng Total } \\
\text { (koloni/gram) }\end{array}$} \\
\hline & $8 \mathrm{Jam}$ & $\begin{array}{c}10 \\
\text { Jam }\end{array}$ & $\begin{array}{c}12 \\
\text { Jam }\end{array}$ \\
\hline \multicolumn{4}{|l|}{ Kontrol } \\
\hline Replikasi I & 647.5 & 748.5 & 925 \\
\hline Replikasi II & 677.5 & 768.5 & 919 \\
\hline Rata-rata & 662.5 & 767.5 & 922 \\
\hline \multicolumn{4}{|l|}{$\begin{array}{l}\text { Bawang } \\
\text { Putih }\end{array}$} \\
\hline Replikasi I & 558.5 & 527.4 & 311.5 \\
\hline Replikasi II & 539 & 526 & 380.5 \\
\hline Rata-rata & 548.8 & 526.7 & 346 \\
\hline $\begin{array}{l}\text { Rata-rata } \\
\text { Penurunan }\end{array}$ & 113.8 & 240.8 & 576 \\
\hline $\begin{array}{l}\text { Rata-rata \% } \\
\text { Penurunan }\end{array}$ & $17,2 \%$ & $31,4 \%$ & $62,5 \%$ \\
\hline
\end{tabular}

Pada tabel 1 terlihat jumlah kuman pada kontrol pada penyimpanan selama 8 jam yaitu $662.500 \mathrm{koloni} / \mathrm{gram}, 10 \mathrm{jam} 767.000 \mathrm{koloni} / \mathrm{gram}$, dan pada $12 \mathrm{jam} 922.000 \mathrm{koloni} / \mathrm{gram}$. Pada ikan dengan pelumuran bawang putih menunjukkan jumlah kuman selama pelumuran 8 jam 548.000 koloni/gram, 10 jam 526.700 koloni/gram, dan pada 12 jam 346.000 koloni/gram.

\section{Pelumuran dengan Jahe}

Hasil pemeriksaan jumlah kuman dengan pelumuran dan tanpa pelumuran jahe masingmasing 20 gram pada 100 - 105 gram pada ikan kembung dengan waktu pelumuran berbeda yakni 8 jam, 10 jam dan 12 jam yang dilaksanakan pada tanggal 9 - 10 Mei 2017, dapat dilihat pada tabel 2 berikut ini : 
Tabel 2

Hasil Pemeriksaan ALT Pada Ikan Segar Dengan Pelumuran Jahe

\begin{tabular}{cccc}
\hline & \multicolumn{3}{c}{$\begin{array}{c}\text { Angka Lempeng Total } \\
\text { (koloni/gram) }\end{array}$} \\
\cline { 2 - 3 } Perlakuan & \multicolumn{3}{c}{10} \\
& 8 Jam & Jam & 12 Jam \\
\hline Kontrol & & & \\
Replikasi I & 648 & 749 & 925 \\
Replikasi II & 678 & 769 & 919 \\
Rata-rata & 663 & 768 & 922 \\
\hline Jahe & & & \\
Replikasi I & 528 & 515 & 347.6 \\
Replikasi II & 585 & 563 & 382.1 \\
Rata-rata & 556 & 539 & 364.85 \\
\hline Rata-rata & \multicolumn{3}{|}{} \\
Penurunan & 106 & 230 & 557,150 \\
\hline Rata-rata \% & \multicolumn{3}{c}{} \\
Penurunan & $16,2 \%$ & $29,9 \%$ & $60,5 \%$ \\
\hline
\end{tabular}

Pada tabel 2 terlihat jumlah kuman pada kontrol selama 8 jam sebanyak 662.500 koloni/gram, 10 jam sebanyak 767.000 koloni/gram, dan pada 12 jam sebanyak 922.000 koloni/gram.

Pada ikan dengan pelumuran jahe menunjukkan jumlah kuman selama pelumuran selama 8 jam sebanyak 556.000 koloni/gram, 10 jam sebanyak 538.000 koloni/gram, dan pada 12 jam sebanyak 364.000 koloni/gram.

Dari hasil tersebut menunjukkan adanya perbedaan jumlah kuman dengan pelumuran dan tanpa pelumuran bawang putih dan pelumuran jahe dengan waktu perlakuan 8 jam, 10 jam, dan 12 jam.

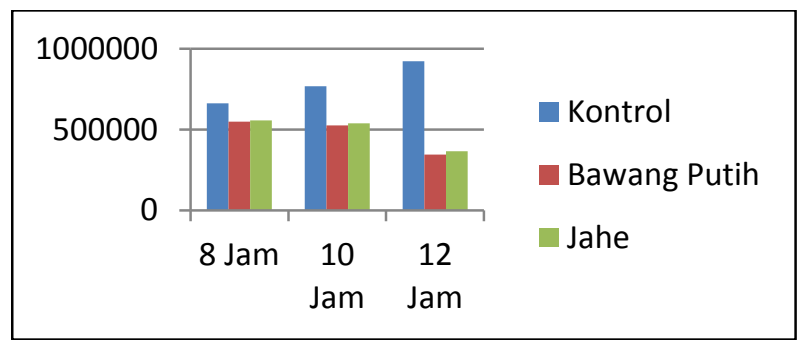

Gambar 1 Perbandingan Angka Lempeng Total Ikan Segar Pada Pelumuran Bawang Putih Dengan Jahe
Berdasarkan gambar 1 terlihat pada kontrol jumlah kuman terus mengalami peningkatan. Sedangkan hasil penelitian terhadap pelumuran bawang putih dan pelumuran dengan jahe pada ikan kembung mempunyai pengaruh sebagai antimikroba. Dari kedua bahan yang digunakan yaitu bawang putih dan jahe, mampu menghambat pertumbuhan koloni bakteri setelah peyimpanan selama 8 jam, $10 \mathrm{jam}$, dan $12 \mathrm{jam}$. Hasil pemeriksaan menunjukkan kemampuan bawang putih sebagai antimikroba pada ikan kembung lebih besar dalam menghambat pertumbuhan koloni bakteri dibanding dengan kamampuan jahe.

\section{Nilai Organoleptik Ikan Kembung}

Dalam penelitian ini dilakukan pula pengamatan secara fisik pada ikan kembung dengan pelumuran dan tanpa pelumuran bawang putih dan jahe masing-masing 20 gram pada 100 - 105 gram ikan kembung dengan waktu pelumuran berbeda yakni 8 jam, 10 jam dan 12 jam. Adapun hasil pengamatan organoleptik pada ikan kembung sebagai berikut :

Tabel 3

Nilai Organoleptik Ikan Segar Pada Pelumuran Bawang putih

\begin{tabular}{|c|c|c|c|c|c|c|c|c|c|c|c|c|c|}
\hline \multirow{5}{*}{$\begin{array}{l}\mathrm{N} \\
\mathrm{O}\end{array}$} & \multirow{5}{*}{$\begin{array}{l}\text { Spesifik } \\
\text { asi }\end{array}$} & \multicolumn{12}{|c|}{ Perlakuan } \\
\hline & & \multicolumn{6}{|c|}{ Kontrol } & \multicolumn{6}{|c|}{ Bawang Putih } \\
\hline & & \multicolumn{2}{|c|}{$8 \mathrm{Jam}$} & \multicolumn{2}{|c|}{$10 \mathrm{Jam}$} & \multicolumn{2}{|c|}{$12 \mathrm{Jam}$} & \multicolumn{2}{|c|}{$8 \mathrm{Jam}$} & \multicolumn{2}{|c|}{$10 \mathrm{Jam}$} & \multicolumn{2}{|c|}{12 Jam } \\
\hline & & $\mathrm{R}$ & $\mathrm{R}$ & $\mathrm{R}$ & $\mathrm{R}$ & $\mathrm{R}$ & $\mathrm{R}$ & $\mathrm{R}$ & $\mathrm{R}$ & $\mathrm{R}$ & $\mathrm{R}$ & $\mathrm{R}$ & $\mathrm{R}$ \\
\hline & & 1 & 2 & 1 & 2 & 1 & 2 & 1 & 2 & 1 & 2 & 1 & 2 \\
\hline 1 & Mata & 7 & 7 & 6 & 6 & 5 & 5 & 8 & 8 & 8 & 8 & 8 & 8 \\
\hline 2 & $\begin{array}{c}\text { Lendir } \\
\text { Permuk } \\
\text { aan } \\
\text { Badan }\end{array}$ & 7 & 7 & 6 & 6 & 5 & 5 & 8 & 8 & 8 & 8 & 8 & 8 \\
\hline 3 & Daging & 7 & 7 & 6 & 6 & 5 & 5 & 8 & 8 & 8 & 8 & 8 & 8 \\
\hline 4 & $\mathrm{Bau}$ & 7 & 7 & 6 & 6 & 5 & 5 & 8 & 8 & 8 & 8 & 8 & 8 \\
\hline 5 & Tekstur & 7 & 7 & 6 & 6 & 5 & 5 & 8 & 8 & 8 & 8 & 8 & 8 \\
\hline \multicolumn{2}{|c|}{ Rata - rata } & \multicolumn{2}{|c|}{7} & \multicolumn{2}{|c|}{6} & \multicolumn{2}{|c|}{5} & \multicolumn{2}{|c|}{8} & & & \multicolumn{2}{|c|}{8} \\
\hline
\end{tabular}

Ket :

$\mathrm{R} 1$ : replikasi 1

R2 : replikasi 2

Pada tabel 3 diatas menunjukkan nilai organoleptik pada kontrol selama 8 jam dengan nilai rata-rata 7 dari keseluruhan penilaian organoleptik, kontrol 10 jam dengan rata-rata nilai 6 dari keseluruhan penilaian organoleptik, dan kontrol 12 jam dengan rata-rata nilai 5 dari keseluruhan penilaian organoleptik. 
Pada ikan kembung dengan pelumuran bawang putih menunjukkan rata- rata nilai organoleptik selama pelumuran 8 jam dengan rata-rata nilai 8 dari keseluruhan penilaian organoleptik, pelumuran 10 jam dengan ratarata nilai 8 dari keseluruhan penilaian organoleptik, dan pada pelumuran selama 12 dengan rata-rata nilai 8 dari keseluruhan penilaian organoleptik.

\section{Tabel 4}

Nilai Organoleptik Ikan Segar Pada Pelumuran Jahe

\begin{tabular}{|c|c|c|c|c|c|c|c|c|c|c|c|c|c|}
\hline \multirow{5}{*}{$\begin{array}{l}\mathrm{N} \\
\mathrm{O}\end{array}$} & \multirow{5}{*}{$\begin{array}{l}\text { Spesif } \\
\text { ikasi }\end{array}$} & \multicolumn{12}{|c|}{ Perlakuan } \\
\hline & & \multicolumn{6}{|c|}{ Kontrol } & \multicolumn{6}{|c|}{ Jahe } \\
\hline & & \multicolumn{2}{|c|}{$8 \mathrm{Jam}$} & \multicolumn{2}{|c|}{$\begin{array}{c}10 \\
\text { Jam } \\
\end{array}$} & \multicolumn{2}{|c|}{$\begin{array}{c}12 \\
\text { Jam } \\
\end{array}$} & \multicolumn{2}{|c|}{$8 \mathrm{Jam}$} & \multicolumn{2}{|c|}{$\begin{array}{c}10 \\
\text { Jam } \\
\end{array}$} & \multicolumn{2}{|c|}{$\begin{array}{c}12 \\
\text { Jam }\end{array}$} \\
\hline & & & & $\mathrm{R}$ & $\mathrm{R}$ & $\mathrm{R}$ & $\mathrm{R}$ & $\bar{R}$ & $\bar{R}$ & $\mathrm{R}$ & $\mathrm{R}$ & $\mathrm{R}$ & F \\
\hline & & 1 & & 1 & 2 & 1 & 2 & 1 & 2 & 1 & 2 & 1 & 2 \\
\hline 1 & Mata & 7 & 7 & 6 & 6 & 5 & 5 & 8 & 8 & 8 & 8 & 8 & 8 \\
\hline & $\begin{array}{c}\text { Lendir } \\
\text { Perm } \\
\text { ukaan }\end{array}$ & & & & & & & & & & & & \\
\hline 2 & Badan & 7 & 7 & 6 & 6 & 5 & 5 & 8 & 8 & 8 & 8 & 8 & 8 \\
\hline 3 & $\begin{array}{c}\text { Dagin } \\
\mathrm{g}\end{array}$ & 7 & 7 & 6 & 6 & 5 & 5 & 8 & 8 & 8 & 8 & 8 & 8 \\
\hline 4 & Bau & 7 & 7 & 6 & 6 & 5 & 5 & 8 & 8 & 8 & 8 & 8 & $\varepsilon$ \\
\hline & Tekst & & & & & & & & & & & & \\
\hline 5 & ur & 7 & 7 & 6 & 6 & 5 & 5 & 8 & 8 & 8 & 8 & 8 & $\varepsilon$ \\
\hline & $\begin{array}{l}\text { Rata - } \\
\text { rata }\end{array}$ & & & & & & & & & & & & \\
\hline
\end{tabular}

Ket :

$\mathrm{R} 1$ : replikasi 1

$\mathrm{R} 2$ : replikasi 2

Pada tabel 4 diatas menunjukkan nilai oragnoleptik pada kontrol selama 8 jam dengan nilai rata-rata 7 dari keseluruhan penilaian organoleptik, kontrol 10 jam dengan rata-rata nilai 6 dari keseluruhan penilaian organoleptik, dan kontrol 12 jam dengan rata-rata nilai 5 dari keseluruhan penilaian organoleptik.

Pada ikan kembung dengan pelumuran jahe menunjukkan rata- rata nilai organoleptik selama pelumuran 8 jam dengan rata-rata nilai 8 dari keseluruhan penilaian organoleptik, pelumuran 10 jam dengan rata-rata nilai 8 dari keseluruhan penilaian organoleptik, dan pada pelumuran selama 12 dengan rata-rata nilai 8 dari keseluruhan penilaian organoleptik.

\section{PEMBAHASAN}

Ikan merupakan salah satu bahan pangan yang mudah rusak, terutama ikan segar. Ikan cepat mengalami proses pembusukan dibandingkan dengan bahan makanan lain yang disebabkan oleh bakteri dan perubahan kimiawi pada ikan mati. Kerusakan ikan terjadi segera setelah ikan keluar dari air (Susanti, 2013).

Dasar pengawetan ikan adalah mempertahankan ikan selama mungkin dengan cara menghambat atau menghentikan beberapa aktivitas bakteri pembusuk yang ada pada tubuh ikan. Pengawetan merupakan upaya yang dilakukan untuk memperpanjang waktu penyimpanan bahan pangan.

Salah satu strategi untuk mengurangi jumlah bakteri dapat dilakukan dengan mengaplikasikan antimikroba pada saat proses pengolahan pangan untuk mencegah pertumbuhan mikroba. Antibakteri alami yang populer dikalangan masyarakat yaitu seperti bawang putih dan jahe.

Untuk itu penelitian ini dilakukan untuk mengetahui kemampuan bawang putih dan jahe sebagai antimikroba pada ikan segar agar dapat membantu masyarakat dalam mempertahankan mutu dan kesegaran ikan. Penggunaan bahan alami ini diharapkan dapat mengurangi kecepatan kemunduran mutu ikan terutama dalam menghambat aktivitas mikroba yaitu dengan memberikan pelumuran bawang putih dan jahe masing-masing sebanyak 20 gram untuk 100 105 gram ikan. Bawang putih dan jahe diketahui memiliki sifat sebagai agen antibakteri, yang mampu menghambat pertumbuhan beberapa bakteri penyebab penyakit. Untuk mengetahui secara jelas berdasarkan teori akan dibahas sebagai berikut :

\section{Kemampuan Bawang Putih (Allium sativum) Sebagai Antimikroba Pada Ikan Segar}

Salah satu senyawa kimia yang terkandung dalam bawang putih yang mempunyai khasiat sebagi antibakteri adalah allicin. Allicin dapat dihasilkan dengan mengiris dan menghaluskan umbi bawang putih. Aktivitas antibakteri bawang putih sebagian besar karena allicin yang muncul ketika sel bawang putih rusak. Kerusakan pada sel bawang putih akan mengaktifkan enzim allinase merubah aliin menjadi allicin. Allicin dan derivatnya mempunyai efek menghambat secara total sintesis ARN dan menghambat secara persial pada sintesis ADN dan protein. Allicin bekerja dengan cara memblok enzim bakteri yang memiliki gugus thiol yang akhirnya menghambat pertumbuhan bakteri. Allicin merupakan 
senyawa sulfur yang reaktif dan cenderung tidak stabil yang mempunyai kemampuan untuk melawan katalisator biologis (enzim) khususnya yang berada didalam atau dibawah lapisan bakteri yang dibutuhkan untuk pertumbuhan dan reproduksi bakteri (Ramadanti, 2008).

Berdasarkan hasil pemeriksaan yang dilakukan dengan pelumuran 20 gram bawang putih pada 100 - 105 gram ikan kembung yang kemudian didiamkan pada suhu ruang $25-27^{\circ} \mathrm{C}$ selama 8 jam, 10 jam, dan 12 jam mengalami penurunan jumlah kuman dibanding dengan kontrol selama 8 jam, 10 jam, dan 12 jam.

Penurunan jumlah kuman pada pelumuran bawang putih selama 8 jam menunjukkan hasil adanya penurunan jumlah kuman terhadap jumlah kuman pada kontrol. Pada kontrol selama 8 jam menujukkan jumlah kuman sebanyak 662.500 koloni/gram, sedangkan untuk pada

pelumuran selama 8 jam menunjukkan jumlah kuman sebanyak $548.750 \mathrm{koloni} / \mathrm{gram}$ dengan persentase penurunan $17,2 \%$. Penurunan jumlah kuman juga terjadi pada perlakuan 10 jam dan 12 jam. Pada kontrol selama 10 jam menujukkan jumlah kuman 767.500 koloni/gram, sedangkan pada pelumuran selama 10 jam menunjukkan jumlah kuman 526.700 koloni/gram dengan persentase penurunan 31,4\%. Kontrol 12 jam menujukkan jumlah kuman sebanyak 922.000 koloni/gram, sedangkan pada pelumuran 12 jam menunjukkan jumlah kuman 346.000 koloni/gram dengan persentase penurunan $60,5 \%$.

Berdasarkan hasil pemeriksaan jumlah kuman pada ikan mengalami penurunan jumlah kuman dari tiap lama pelumuran. Namun pada pelumuran 8 jam dan 10 jam, penurunan cenderung lebih rendah daripada perlakuan pada 12 jam. Hal ini dikarenakan allisin yang ada pada hancuran bawang putih belum meresap secara keseluruhan pada tubuh ikan sehingga penurunan jumlah kuman pada 8 jam dan 10 jam masih cenderung rendah. Tetapi setelah perlakuan selama 12 jam terjadi penurunan yang baik dan jumlah kuman telah memenuhi SNI 2013 dengan hasil yang diperoleh 346.000 koloni/gram.
Penurunan jumlah kuman terjadi karena adanya proses penyerapan bawang putih didalam daging ikan mengakibatkan aktivitas mikroba berkurang, dan allicin yang terbentuk dalam hancuran bawang putih mempunyai kemampuan untuk memblok enzim bakteri yang memiliki gugus thiol yang berada didalam atau dibawah lapisan bakteri yang pada akhirnya menghambat pertumbuhan bakteri.

Hal ini sesuai dengan penelitian Nilam Syifa dkk., (2013) yang menyatakan bahwa ekstrak bawang putih yang dilarutkan dalam air bersifat antibakteri terhadap bakteri gram positif dan gram negatif, pemberian ekstrak bawang putih efektif menghambat pertumbuhan bakteri dengan konsentrasi paling efektif $10 \%$ serta waktu penyimpanan maksimal adalah 24 jam. Ekstrak bawang putih menggunakan pelarut aquades steril pada suhu ruang (antara $25-27^{\circ} \mathrm{C}$ ) dapat menghasilkan allicin sebagai zat antibakteri yang menghambat pertumbuhan koloni bakteri.

Jika diliat dari tabel 1 pemeriksaan jumlah kuman pada pelumuran selama 8 jam dan 10 jam diperoleh hasil jumlah kuman yang tidak memenuhi syarat SNI 2013 tentang syarat mutu dan keamanan pangan ikan segar $=5 \times 105$ koloni $/ g r a m$. Adapun setelah pelumuran selama 12 jam telah memenuhi syarat dengan jumlah kuman 346.000 koloni/gram dengan persentase penurunan $62,5 \%$.

\section{Kemampuan Jahe (Zingeber Officinale)} Sebagai Antimikroba Pada Ikan Segar

Jahe merupakan salah satu rempahrempah yang telah dikenal luas oleh masyarakat. Jahe digunakan sebagai penguat rasa dan aroma pada proses pembuatan bahan makanan karena mengandung flavonoid, polifenol, dan minyak atsiri.

Jahe mampu menghambat pertumbuhan mikroba disebabkan karena adanya kandungan senyawa metabolisme sekunder yang terdapat pada tanaman jahe, yaitu golongan fenol seperti gingerol, paradol, shogaol, zingerone, resin dan minyak atsiri. Senyawa-senyawa metabolisme sekunder tersebut dapat menghambat pertumbuhan mikroba pathogen dan perusak pangan. Beberapa senyawa turunan fenol juga 
mampu menurunkan tegangan permukaan sel. Hal ini disebakan karena membran sel tersusun atas protein dan lipid sangat rentan terhadap senyawa fenol.Kerusakan membran sel menyebabkan terganggunya transport nutrisi (senyawa dan ion) melalui mebran sel sehingga sel mikroba mengalami kekurangan nutrisi yang diperlukan bagi pertumuhannya.

Berdasarkan hasil pemeriksaan yang dilakukan dengan pelumuran 20 gram jahe pada 100 - 105 gram ikan yang kemudian didiamkan pada suhu ruang $25-27^{\circ} \mathrm{C}$ selama 8 jam, 10 jam, 12 jam mengalami penurunan jumlah kuman dibanding dengan kontrol selama 8 jam, 10 jam, dan 12 jam.

Berdasarkan hasil pemeriksaan jumlah kuman pada ikan mengalami penurunan jumlah kuman dari tiap lama pelumuran.Namun pada pelumuran 8 jam dan 10 jam, penurunan cenderung lebih rendah daripada perlakuan pada 12 jam. Hal ini dikarenaka senyawa fenol yang ada pada jahe belum bekerja secara maksimal pada tubuh ikan sehingga penurunan jumlah kuman pada 8 jam dan 10 jam masih cenderung rendah. Tetapi setelah pelumuran selama 12 jam terjadi penurunan yang baik dan jumlah kuman telah memenuhi SNI 2013 dengan hasil yang diperoleh 364.000 koloni/gram.

Penurunan jumlah kuman setelah pelumuran jahe selama 8 jam menunjukkan hasil adanya penurunan jumlah kuman terhadap jumlah kuman pada kontrol. Pada kontrol 8 jam menunjukan jumlah kuman sebanyak 662.500 koloni/gram, sedangkan pada pelumuran selama 8 jam menunjukkan jumlah kuman sebanyak 556.025 koloni/gram dengan persentase penurunan 16,2\%. Penurunan jumlah kuman juga terjadi pada pelumuran 10 jam dan 12 jam. Kontrol 10 jam menujukkan jumlah kuman sebanyak 767.500 koloni/gram, sedangkan pada pelumuran selama 10 jam menunjukkan jumlah kuman sebanyak 538.750 koloni/gram dengan persentase penurunan 29,9\%. Kontrol 12 jam menujukkan jumlah kuman sebanyak 922.000 koloni/gram, sedangkan pada pelumuran selama 10 jam menunjukkan jumlah kuman sebanyak 364.000 koloni/gram dengan persentase penurunan $60,5 \%$.

Berdasarkan hasil pemeriksaan jumlah kuman pada ikan mengalami penurunan jumlah kuman dari tiap lama pelumurannya. Penurunan jumlah kuman terjadi karena adanya proses penyerapan jahe didalam daging ikan mengakibatkan aktivitas mikroba berkurang,dan kerusakan yang dapat terjadi pada sel mikroba akibat pemberian jahe. Penghambatan pertumbuhan sel mikroba oleh komponen fenol memiliki kemampuan untuk mendenatursi protein dan merusak membran sel dengan cara melarutkan lemak yang terdapat pada dinding sel. Sehingga dinding sel mengalami kerusakan. Tanpa dinding sel mikroba tidak dapat tahan terhadap pengaruh luar dan akan segera mati.

Hal ini sesuai dengan penelitian Purnawi Eni dan Setyo Wulan Nur Hapsari (2011) menggunakan ekstrak jahe dalam menghambat mikroba perusak pada ikan nila memperoleh hasil bahwa terdapat pengaruh pada penghambatan mikroba antara yang diberikan konsentrasi ekstrak jahe dengan tanpa pemberian ekstrak jahe. Hasil pengujian daya hambat mikroba dari ekstrak jahe $(50 \%, 60 \%$, dan $70 \%)$ mampu menghambat pertumbuhan mikroba yang terdapat pada ikan nila. Namun bedanya pada penelitian yang sekarang hanya menggunakan jahe tanpa diekstrak terlebih dahulu.

Jika diliat dari tabel 5.1 pemeriksaan jumlah kuman pada pelumuran selama 8 jam dan 10 jam diperoleh hasil jumlah kuman yang tidak memenuhi syarat SNI 2013 tentang syarat mutu dan keamanan pangan ikan segar $=5 \times 10^{5} \mathrm{koloni} / \mathrm{gram}$. Adapun setelah pelumuran selama 12 jam telah memenuhi syarat jumlah kuman sebanyak 364.000 koloni/gram dengan persentase penurunan $60,5 \%$.

\section{Nilai Organoleptik Pada Ikan Kembung}

Adapun untuk pengamatan organoleptik ikan kembung dengan pelumuran dan tanpa pelumuran bawang putih dan jahe selama 8 jam, 10 jam dan 12 jam mengalami perubahan pula. Perubahan terjadi disetiap spesifikasi penilaian yaitu mata, lendir, daging, bau dan tekstur.

Pada penyimpanan 8 jam untuk spesifikasi mata diperoleh nilai 7 yang berarti bola mata rata, kornea agak keruh, pupil agak keabu-abuan, agak mengkilap spesifik jenis ikan. Untuk lendir pada permukaan badan diperoleh nilai 7 yang berarti lapisan lendir 
mulai agak keruh, untuk spesifikasi daging diperoleh nilai 7 yang berarti sayatan daging sedikit kurang cemerlang, jaringan daging kuat. Untuk bau diperoleh nilai 7 yang berarti bau ikan masih segar, tetapi spesifik jenis ikannya mulai kurang. Terakhir untuk spesifik teksturnya diperoleh nilai 7 yang berarti tekstur ikan tersebut agak lunak, dan agak elastis.

Pada penyimpanan 10 jam ikan mengalami penurunan nilai. Untuk spesifikasi mata diperoleh nilai 6 yang berarti bola mata agak cekung, kornea agak keruh, pupil agak keabu-abuan, agak mengkilap spesifik jenis ikan. Untuk lendir pada permukaan badan diperoleh nilai 6 yang berarti lapisan lendir mulai keruh, untuk spesifikasi daging diperoleh nilai 6 yang berarti sayatan daging sedikit kurang cemerlang, jaringan daging kurang kuat. Untuk bau diperoleh nilai 6 yang berarti netral. Terakhir untuk spesifik teksturnya diperoleh nilai 6 yang berarti tekstur ikan tersebut agak lunak, dan sedikit kurang elastis.

Pada penyimpanan 12 jam ikan juga mengalami penurunan nilai. Untuk spesifikasi mata diperoleh nilai 5 yang berarti bola mata agak cekung, kornea keruh, pupil agak keabu-abuan, tidak mengkilap. Untuk lendir pada permukaan badan diperoleh nilai 5 yang berarti lendir agak tebal, mulai berubah warna. Untuk spesifikasi daging diperoleh nilai 5 yang berarti sayatan daging mulai pudar, jaringan daging kurang kuat. Untuk bau diperoleh nilai 5 yang bau ikan mulai asam. Terakhir untuk spesifik teksturnya diperoleh nilai 5 yang berarti tekstur ikan tersebut agak lunak, dan kurang elastis.

Untuk pengamatan organoleptik dengan perlakuan pelumuran dengan bawang putih dan dengan jahe selama 8 jam, 10 jam dan 12 jam tidak mengalami perubahan baik itu mata, lendir, daging, dan bau serta teksturnya, tetap mempertahan nilai mutu ikan tersebut.

Pada penyimpanan baik itu 8 jam, 10 jam dan 12 jam ikan tidak mengalami penurunan nilai. Untuk spesifikasi mata diperoleh nilai 8 yang berarti bola mata rata, kornea dan pupil jernih, agak mengkilap spesifik. Untuk lendir pada permukaan badan diperoleh nilai 8 yang berarti lapisan lendir jernih, transparan, cukup cerah. Untuk spesifikasi daging diperoleh nilai 8 yang berarti sayatan daging cemerlang spesifik jenis, jaringan daging kuat. Untuk bau diperoleh nilai 8 yang berarti bau ikan segar, spesifik jenis. Terakhir untuk spesifik teksturnya diperoleh nilai 8 yang berarti tekstur ikan masih padat, kompak, dan elastis.

Dari pembahasan diatas dapat dilihat kemampuan bawang putih sebagai antimikroba pada ikan segar lebih besar dalam menghambat pertumbuhan kuman dibanding dengan kamampuan jahe. Hal ini dikarenakan dari rata-rata penurunan jumlah kuman pada pelumuran bawang putih yaitu sebanyak 310.183 koloni/gram dengan persentase $62,5 \%$. Sedangkan rata-rata penurunan jumlah kuman pada pelumuran jahe sebanyak 297.992 koloni/gram.

Penurunan ini terjadi karena pengaruh lama pelumuran bawang putih dan jahe yang diberikan. Semakin lama pelumuran maka semakin menurun pula jumlah kuman pada ikan. Hasil pemeriksaan menunjukkan penurunan jumlah kuman paling besar pada pelumuran selama 12 jam. Pelumuran dengan bawang putih selama 12 jam memperoleh jumlah kuman 346.000 koloni/gram dan pelumuran dengan jahe memperoleh jumlah kuman 364.000 koloni/gram, hasil tersebut telah sesuai dengan SNI 2013 tentang mutu dan keamanan pangan ikan segar dengan jumlah kuman 364.000 koloni/gram dengan persentase penurunan $60,5 \%$.

Perbedaan penelitian ini dengan penelitian-penelitian sebelumnya adalah pada penelitian-penelitian sebelumnya menggunakan ekstrak bawang putih maupun jahe dalam menghambat pertumbuhan mikroba pada ikan segar sedangkan pada penelitian yang sekarang hanya menggunakan hancuran bawang putih dan jahe. Dimana diketahui jika ingin diaplikasikan kepada masyarakat akan sulit jika harus menggunakan ekstrak.

Pelumuran hancuran bawang putih atau dengan jahe pada ikan segar akan mudah dilakukan oleh masyarakat karena hanya perlu menghancurkannya kemudian melumurkan diseluruh tubuh ikan. Pengawetan ikan dengan menggunakan bawang putih ataupun jahe dapat diaplikasikan ketika seseorang ingin melakukan perjalanan di tempat yang tidak 
Jurnal Sulolipu : Media Komunikasi Sivitas Akademika dan Masyarakat

Vol. 17 No.II 2017

e-issn : 2622-6960, p-issn : 0854-624X

menggunakan lemari es seperti ketika akan melakukan pendakian gunung tetapi ingin membawa ikan segar, kita dapat memberikan pelumuran bawang putih pada ikan tersebut sehingga tidak perlu merasa khawatir apabila ikan tersebut disimpan selama 12 jam.

\section{PENUTUP}

\section{Kesimpulan}

Berdasarkan penelitian yang dilakukan diperoleh hasil bahwa bawang putih (Allium sativum) memiliki kemampuan sebagai antimikroba lebih besar dibanding dengan kemampuan jahe (Zingeber Officinale) sebagai antimikroba. Berikut uraian kesimpulan dari penelitian ini sebagai berikut :

a. Bawang putih (Allium sativum) mampu menghambat pertumbuhan mikroba pada ikan segar dengan adanya penurunan jumlah kuman setelah perlakuan dengan rata-rata penurunan sebanyak 310.183 koloni/gram $(39,6 \%)$ dan memenuhi syarat SNI 2729 : 2013 yaitu $5 \times 10^{5}$ koloni/gram setelah perlakuan selama 12 jam. b. Jahe (Zingeber officinale) mampu menghambat pertumbuhan mikroba pada ikan segar dengan menunjukkan penurunan jumlah kuman setelah perlakuan dengan rata-rata penurunan sebanyak 297.992 koloni/gram (38\%) dan memenuhi syarat SNI $2729: 2013$ yaitu 5 X $10^{5} \mathrm{koloni} / \mathrm{gram}$ setalah perlakuan selama 12 jam.

\section{Saran}

a. Diharapkan kepada masyarakat untuk memanfaatkan bawang putih dan jahe sebagai pengawet alami pada ikan segar.

b. Untuk penelitian selanjutnya diharapkan untuk meneliti kemampuan bawang putih dan jahe sebagai antimikroba dengan variasi berat bahan yang berbeda dengan waktu yang melebihi 12 jam.

\section{DAFTAR PUSTAKA}

Afrianti, L.H. 2013. Teknologi Pengawetan Pangan. Bandung: Alfabeta

Handrianto, P. 2016. Uji Antibakteri Ekstrak Jahe Merah Zingiber Officinale Var. Rubrum Terhadap Staphylococcus Aureus Dan Escherichia Coli.Journal of Research and Technologies.Surabaya. (Online):http//:journal.unusida.ac.id/ index.php/jrt/article/view/14/2 Diakses padatanggal 07 Januari ,201718:47:12

Hijriy, L. 2015. Pengaruh Pemberian Sari Jahe (ZingiberOfficinale) Terhadap Jumlah Koloni Bakteri Padalkan Tongkol (EuthynnusAffinis). Jurnal Studi Pendidikan Biologi. Universitas Muhammadiyah. Malang. (Online) : http//biology.umm.ac.id/files/ file/339345\%20Layli\%20Hijriy.pdf. Diakses pada 07 Januari 2017, 18:53:25

Lestari, R.R. 2016. Pengaruh Penambahan Jahe Dan Bawang Putih Terhadap Daya Terima Dan Kadar Protein Bubuk Instan Ekstrak Ikan Gabus (Ophiocephalus Striatus). Jurnal Department Of Nutrition Faculty Of Health Sciences. Akademika Universitas Esa Unggul. Jakarta Barat. (Online) : http://digilib.esaunggul.ac. Diakses pada tanggal 07Januari ,201721:30:47

Purwani Eni dan Setyo Wulang Nur Hapsari, 2011. Pengaruh Ekstrak Jahe (Zingiber officinale) Terhadap Penghambatan Mikroba Perusak Pada Ikan Nila (Oreochromis niloticus). Jurnal Kesehatan. Universitas Muhammadiyah Surakarta

Ramadanti, I.A. 2008. Uji Aktivitas Antibakteri Ekstrak Bawang Putih (Allium Sativum Linn) Terhadap Bakteri Escherichia Coli In Vitro. Artikel Karya Tulis IImiah. Program Pendidikan Sarjana Fakultas Kedokteran. Semarang. Online) : http//prints.undip.ac.id/23957/1/ Irmudita.pdf. Diakses pada tanggal 07 ari Janu2017, 19:00:18 
Jurnal Sulolipu : Media Komunikasi Sivitas Akademika dan Masyarakat

Vol. 17 No.II 2017

e-issn : 2622-6960, p-issn : 0854-624X

Siburian, dkk,. 2012. Pengaruh Suhu dan Waktu Penyimpanan Terhadap Pertumbuhan Bakteri dan Fungi Ikan Bandeng. Ilmu pengetahuan

Standar Nasional Indonesia. 2013. Ikan Segar. (Online) : http://server2. docfoc.com/uploads/Z2015/11/30/PZeCRqCzkB/2597cfdb12ac6a5f4156fd3ec3e66fd6.pdf.

Diakses pada tanggal 26 Januari 2017

Susanti, Mariana. 2013. Mutulkan Tongkol (Euthynnusaffinis C.) Di Kabupaten Gunung kidul dan Sleman Daerah Istimewa Yogyakarta. Penelitian. Yogyakarta. (Online) : e-journal.uajy.ac.id /4380/. Diakses pada tanggal 07 Januari 2017, 21:33:50

Susanto, E., Dkk. 2011. Pemanfaatan Bahan Alami Untuk Memperpanjang Umur Simpan Ikan Kembung (Rastrelliger Neglectus). Jurnal Perikanan. Universitas Gadjah Mada. Yogyakarta. (Online) : https://journal.ugm.ac.id/jfs/article/ view/ 3063. Diakses pada tanggal 07Januari ,201722:01:01

Syifa, N. 2013. Uji Efektivitas Ekstrak Bawang Putih (Allium Sativum Linn.) Sebagai Antibakteri Pada Ikan Bandeng (Chanos Chanos Forsk) Segar. Unnes Journal Of Life Science. Semarang. (Online) : http:// journal.unnes.ac.id/sju/index.php/ UnnesJLifeSci. Diakses pada tanggal 07 Januari 2017, 21:36:16 